\title{
SMALL STEPS
}

AND A BIG

CHANGE:

FACING

INTERNATIONALIZATION

AS A COMMUNITY

PEQUENOS PASSOS E GRANDES MUDANÇAS: ENFRENTANDO A
INTERNACIONALIZAÇÃO COMO UMA COMUNIDADE

PEQUEÑOS PASOS Y GRANDES CAMBIOS: ENFRENTANDO LA INTERNACIONALIZACIÓN

COMO UNA COMUNIDAD

Carla Conti de Freitas*

Giuliana Castro Brossi**

Valéria Rosa-da-Silva ${ }^{* * *}$

State University of Goiás

ABSTRACT: This article presents an extension event that supports internationalization at home in a local context of English teachers' education and social language practices. The event is planned and carried out in a partnership among English teachers in Inhumas, and professors from foreign and local High Education Institutions. The goals of the study are: i) to discuss the role of the process of Internationalization at Home at UEG through an extension action and ii) to point possible contributions of the extension action for English teachers' education in the local community. The empirical material discussed came from reflections during a

\footnotetext{
* PhD in Public Policy, Strategy and Development, UFRJ / UEG and Post-Doctorate at University of Porto Master in Linguistics at Federal University of Goiás (2003). Her interests include language teacher education and technology. Email: professoracarlaconti@gmail.com

** PhD candidate at the Graduate Program in Language Studies at State University of Londrina. She is a teacher educator at the Goias State University in Inhumas. Her main field of research is English to Young Learners Teachers' Education. E-mail: giuliana.brossi@ueg.br.
}

*** Ph.D. student in the graduate program of Federal University of Goiás (Graduate Program in Literature and Linguistics). She is a teacher educator at the Goias State University in Inhumas. Her interests primarily include teacher education and language education. Her research involves mainly critical and decolonial perspectives. Email: valeria.silva@ueg.br. 
meeting in 2018, and from an electronic form in 2019. The discussion revealed the relationship between the event and the internationalization, and the potential expansion of teachers' education during the event which holds a strong community sense that connects teachers from diverse fields, backgrounds, and contexts.

KEYWORDS: University Extension. Teacher education. Intercultural curriculum. Internationalization at home.

RESUMO: Este artigo apresenta um evento extensionista que promove a internacionalização em casa em um contexto local de formação de professores de inglês e prática social da língua. O evento é planejado e realizado em uma parceria entre professores de inglês de Inhumas, formadores de universidades (local e de outros lugares).Os objetivos do estudo são: i) discutir o papel do processo de internacionalização em casa na UEG por meio de um evento de extensão e ii) apontar possíveis contribuições da ação extensionista para a formação de professores da comunidade local. O material empírico discutido veio de reflexões durante uma reunião realizada em 2018 e de um formulário eletrônico respondido em 2019. A discussão revelou a relação entre o evento e a internacionalização, bem como a possível expansão da formação de professores durante o evento que se pauta em um senso forte de comunidade que conecta professores de diversas áreas, experiências e contextos.

PALAVRAS-CHAVE: Extensão universitária. Formação docente. Currículo Intercultural. Internacionalização em casa.

RESUMEN: Este artículo presenta un evento de extensión universitaria que fomenta la internacionalización en casa en un contexto local de formación docente en inglés y práctica social de la lengua. El evento es planeado y llevado a cabo en colaboración entre profesores de inglés de Inhumas, formadores universitarios (locales y de otros lugares). Los objetivos del estudio son: i) discutir el papel del proceso de internacionalización en casa en la UEG por medio de un evento de extensión y ii) señalar posibles contribuciones de la acción de extensión a la formación de docentes en la comunidad local. El material empírico discutido derivó de reflexiones durante una reunión realizada en 2018 y de un formulario electrónico contestado en 2019. La discusión reveló la relación entre el evento y la internacionalización, de la misma manera que la posible expansión de la formación docente durante el evento que está guiado por un fuerte sentido de comunidad que conecta a docentes de diferentes áreas, experiencias y contextos.

PALABRAS CLAVE: Extensión Universitaria. Formación de profesores. Currículo intercultural. Internacionalización en casa.

It's much more than language, it's much more than everything! It's life, it's feeling, it's passion...It was something like good vibration...

(Rose, $M, 2018)^{1}$

\section{INTRODUCTION}

Internationalization has become a frequent discussion in Universities around the world (DE WIT, 2016; GARSON, 2016; STRECK; ABBA, 2018) as well as in Brazil lately (FORTES, 2016; PICCIN;; FINARDI, 2019; BAUMVOL; SARMENTO, 2016). Even though the word internationalization has been widely used in political science and in government discourses (KNIGHT, 2003), it's fairly recent when it comes to Education. According to Piccin and Finardi (2019), although internationalization has been used in the global scenery since the 1980s, in Brazil its use was grounded after the Science without Borders (SwB) Program (FINARDI; ARCHANJO, 2018). Prior to that, however, Baumvol and Sarmento (2016, p. 65) have highlighted the United Nations' official documents which reinforced the University's role in "the poverty eradication, the sustainable development, and world progress", as well as the establishment of the internationalization, regionalization, and globalization of the university as one of the main guiding principles of the High Education Institutions (HEI), set by UNESCO in 2009.

We also corroborate other relevant researchers in the Critical Applied Linguistic field in the sense that the internationalization policies worldwide have been pervaded by inequity, neoliberal commodification, as well as coloniality of knowledge and power

${ }^{1}$ Rose is one the participants of this study.

Freitas, Brossi \& Rosa-da-Silva | Small stepsand a big change: facing internationalization as a community 
(FINARDI, 2019; MENEZES DE SOUZA, 2019²; SOUZA SANTOS, 2018). Besides, we agree with Streck and Abba (2018) regarding the students' capacity for intercultural experience, in an effort to mitigate the obstacles that may interfere in the interaction among people's diverse linguistic and cultural backgrounds, in favor of a critical internationalization.

Furthermore, the internationalization process in many universities in Brazil has been achieving its increasing goals of taking these institutions to a spotlight level in students' mobility just as their publishing goals. A great deal of development happened due to Languages without Borders Program (LwB) and its efforts to supply a second language teaching/learning/use, maximizing the internationalization process, focusing mainly on the English language.

On the other hand, some High Education Institutions, including Goias State University ${ }^{3}$ (hereinafter UEG), struggle to find ways to afford local actions that bring faculty staff, students, and alumni involved in the learning of English, in an attempt to promote an Internationalization at Home (henceforth $\mathrm{IaH}$ ), which will be the focus of this article.

UEG is a state-funded university, recently reorganized into 33 units, divided into eight regional campuses. One of its main achievements is the graduation courses in teachers' education in languages and humanities. As English teachers at UEG Inhumas, a city of approximately 47.000 inhabitants, and $54 \mathrm{~km}$ away from the State's capital, Goiânia, we have decided to include the discussion about $\mathrm{IaH}$ in our routine since we were worried about educating English teachers who are able to value the local community and at the same time prepared for the 21 st Century challenges we will eventually face.

Over the years, a few extension actions have been created by educators from UEG campus Inhumas, more specifically from our Letras (Portuguese and English Language) Course, as a strategy to share experience and promote interaction among English teachers. One of these actions is an event called Foreign Languages Teachers Education Encounter (ENFOPLE ${ }^{4}$ henceforth) which will be presented in this article 5 . For instance, a very important activity during ENFOPLE is the English Immersion Program for Teachers, which are thematic workshops for teachers. Another action is the English for Kids, an English workshop for kids from public schools ${ }^{6}$ that has been going on during ENFOPLE as an enterprise of the English for Kids extension program.

Thus, this case study is situated in the Critical Applied Linguistics area, in the field of teachers' education, focusing on an extension event as a way for IaH. We present English teachers' perceptions and reflections on their participation in the ENFOPLE, as the objectives of this article are: i) to discuss the role of the process of IaH at UEG through an extension action and ii) to point possible contributions of the extension action for English teachers' education in the local community. So, to provide a coherent discussion regarding the Internationalization at Home, initially we intend to present a few concepts and the definitions we consider the theoretical foundation for this paper. Next, we are going to bring a brief scene of the extension, as one of the pieces of HEI trivet. We then present a glimpse of the challenges that 21 st-century teachers have to overcome. We also describe the methodology which has oriented this research, as we finally move on to discuss and analyze the empirical evidence we have gathered. We end up reflecting upon our guiding questions, as well as showing this study's contribution to the field.

\section{UNDERSTANDING INTERNATIONALIZATION AT HOME FROM OUR COMMUNITY POINT OF VIEW}

\footnotetext{
${ }^{2}$ In a communication at the CBLA (Applied Linguistics Brazilian Congress), in Vitória.

${ }^{3}$ We have chosen to use the Portuguese acronym all across the article.

${ }^{4}$ ENFOPLE stands for Encontro de Formação de Professores de Línguas Estrangeiras. Throughout the text we chose to use the Portuguese initials.

${ }^{5}$ For detailed information on ENFOPLE, see Brossi, Silva \& Freitas (2019) or Tavares \& Freitas (2018) or Prado \& Freitas (2015).

${ }^{6}$ See more on Brossi \& Silva (2018) or Egido \&Brossi (2019).
} 
First of all, we understand internationalization as "the process of integrating an international, intercultural, or global dimension into the purpose, functions or delivery of post-secondary education.” (KNIGHT, 2004, p. 11). Although we are aware of how most universities worldwide develop this process through students' mobility, exchange programs, and curriculum adequacy, traveling abroad to study is merely a dream for most of the undergraduate students at UEG for economic reasons. De Wit et al (2015, p. 6) point that there are contradictory tendencies between universities and their attempts for the internationalization movement such as "national priorities versus International trends; government steering versus institutional autonomy; diversification versus harmonization; competition versus cooperation; intellectual property versus open source". All these traits play a role to hamper UEG's internationalization process. Moreover, as UEG is a multi-campus HEI, with 8 campuses, constituted of 33 units scattered over $300.000 \mathrm{~km} 2$ in the state, some endeavors aimed at the development of English as a Foreign Language (henceforth EFL) (such as LwB Program) have been frustrated due to the many obstacles that include the distance between units, low proficiency among students, poor education investment, among others.

As we keep the social aspect of UEG's Foreign Languages Center in mind, with its goal of bringing the community closer to the academic context, it is also intended to allow people to become more aware of the role EFL plays in our globalized world, as we motivate its usage, sensitizing the community about opportunities for interaction. For that reason, UEG has developed different extension actions we have seen as internationalization at home strategies, which we consider as "[...] the purposeful integration of international and intercultural dimensions into the formal and informal curriculum for all students within domestic learning environments" (BEELEN; JONES, 2015, p. 69). According to the authors, reaching students on a domestic level is essential, once it supplies a supportive structure for incoming students and at the same time it comprises "local intercultural learning opportunities into curriculum internationalization" (BEELEN; JONES, 2015, p. 68), which is the main objective of the programs herein described. In the search of a purposeful way to include UEG's students and faculty in internationalization, an immersion program for UEG's staff was developed in 2016 in order to raise awareness about the need for improving international and intercultural aspects of EFL, for the university to go global, as well as for promoting linguistic and cultural changes in the communities where the HEI reaches. Although the immersion program was the first enterprise that involved educators from diverse knowledge fields and from all over the state, UEG Inhumas' initiative goes back to 2006, when the concept of internationalization had not been discussed yet, in most HEI. In July 2006 a group of teachers ${ }^{7}$ of Inhumas, in a partnership with American educators from Brown University, put into action the ArtsLit immersion program (FREITAS, 2010) with the main goal of developing a 'lab school' experience using Artslit ${ }^{8}$ methodology, contributing to the English as a Foreign Language (EFL) teachers' education. The program lasted from July 3rd to July 22nd, and it was centered on the activities provided by American professors who developed the ArtsLit approach that allied emotions, Literature, and language teaching bringing amazement for the 90 teachers and participants from the community. The former Education Secretary has claimed ${ }^{9}$ that " [...] their role was of pure enchantment [...] the teachers were delighted to interact in another language with the American professors ${ }^{10}$.

The experience had such a huge effect on the Secretary that she decided, backed up by the city Mayor, to propose the implementation of English as a Modern Language teaching for city's children aged 6 to 12, which was the kickoff for a new selection of English teachers in 2006, and the beginning of changes in Inhumas Education policies. Since the successful initiative, UEG's professors have promoted the Extension event ENFOPLE. The way we perceive it, extension projects and events at UEG Inhumas have walked hand-in-hand with strategies for the IaH, influencing even the basic education policies in the local scenario (BROSSI, in press), corroborating Ávila (2019) in the sense that the globalization and internationalization process may influence English teaching to children in basic education, or be influenced by it.

\footnotetext{
${ }^{7}$ The group of teachers responsible for organizing the Immersion Program was composed of private English course teachers/entrepreneurs, public schools teachers, the Education Secretary and the city Mayor, as well as UEG's professors.

${ }^{8}$ The Artslit methodology proposes "a classroom praxis that aims at the community's respect and appreciation which allows the human development and constant improvement of pedagogical practices” (FREITAS, 2010, p. 217).

${ }^{9}$ The interview composes the empirical data for Brossi's (in press) doctoral research, which presents the English as a Modern Language for children implementation process, as well as the discussion about teacher education, policies, language planning and its impacts in the local and state communities.

${ }^{10}$ Original in Portuguese: "com os professores dos Estados Unidos simplesmente foi um papel deles de encantamento eles ficaram encantados com a oportunidade de aprender outra língua com os professores dos Estados Unidos”.
} 
Within this scenario, it becomes clear that the extension activities, events, courses, and projects have played an important role in teachers' education, as well as in the development of the community, and eventually in its transformation. According to Kochhann (2019), university extension only assumed a conception of a transformative process in 1987, when the idea of assistance and service provision in extension activities was surpassed. We endorse the author in the sense that extension activities, such as the one presented here, create the terms for stakeholders to change their attitudes, developing some knowledge that enables them to transform their relations, and consequently the society.

We commune with her, as well as with Miguens Jr and Celeste (2014, p. 15) in defining university extension as "[...] a scientific, cultural, and educational process that articulates Teaching and Research in an inseparable way and it makes feasible the transformative relations between university and society".

As we have previously stated regarding the extension activities at UEG Inhumas, the lead professors that create those have in mind the integration of the trivet education, research, and extension that supports Higher Education, promoting " $[\ldots]$ the interrelation between theory and practice for pre-service and in-service EYL [English for Young Learners] teachers" (BROSSI; SILVA; FREITAS, 2019, p. 164).

In the field of English teachers education, Kennedy (2013), Darling-Hammond (2006), McDonald and Zeichner (2009) state that, we, 21st-century teachers, urgently need to be ready for this century's challenges (GEE, 2000) as technological innovations and speed changes progress quickly in the globalizing era, with fluid (re)construction of information and knowledge (BAUMAN, 2001).

For that matter, Zeichner (2010) reinforced the necessity of thinking about connecting teachers' education to real concrete praxis. The partnership between school and university, its goals, settings, and results are discussed by Douglas and Ellis (2011), Furlong et al. (2006), and Breault (2013) showing different ways and diverse results that come from interaction in local and contextual variables in partnerships. Although we are very enthusiastic about the partnerships we've acquired and stabilized over the years in our local scenery, Fairclough (2005) advises us to deeply understand the terms and conceptions that sustain partnerships and their relations, focusing on legitimizing cooperation and collaborations discourses within incompatible power relations to an effective collaborative partnership.

In our own construction as teacher educators, we have been tracing a path that has led us in finding local solutions for localized needs, faced collaboratively through established partnerships cultivated in social relations motivated by mutual concerns. We agree with Darling-Hammond (2006) and Furlong et al. (2006) that partnerships may strengthen schools and universities relations, since it builds mutual trust, enabling the development of praxiologies from the reflections. Breault (2013) reasons for a more consistent and small scale partnership, ecologically established in order to maintain its sustainability. We advocate for that from the context we act upon, with the closeness of smaller groups, for the local actions, particularly in the creation of hybrid spaces to optimize learning and teacher education (ZEICHNER, 2010) such as the extension activities we are presenting here. Besides, we share Darling-Hammond's (2006) view that urges educators to venture out of the limits of the university, approximating pre-service teachers to in-service teachers and their real scenario, where they will be acting. Sustained by all these principles, we have created extension events and activities that aim not only at bringing the internationalization reality closer to our community but also at creating alternative spaces for reflecting upon teachers' education.

Through these alternative hybrid spaces for teachers' education, we hope to join the movement of educating teachers to be more autonomous, reflective, open to research their praxis and able decision-makers, as well as sensitive to particularity, practicality, and possibility (KUMARAVADIVELU, 2003; 2006). We believe that bringing pre-service teachers as well as in-service teachers to the center of the discussion about curriculum design and decision making regarding their education will promote a sense of belonging and consequently further involvement with the same process of development of skills related to teacher praxis, for a transformative, fair and egalitarian education. Furthermore, the strategies to bring the community closer to internationalization, which is one of the goals of the ENFOPLE event, involves pre-service and in-service teachers as well as educators and the community in general, in an effort to expand the post-Method (KUMARAVADIVELU, 2003; 2006) teacher education we are engaged in. 


\section{DESCRIBING OUR PATH}

Caminante, son tushuellas
elcamino y nada más;
caminante, no haycamino,
sehacecamino al andar.
Al andar se haceelcamino,
y al volver la vista atrás
sevela senda que nunca
se ha de volver a pisar.
Caminante no haycamino
sino estelas enla mar.

Antonio Machado ${ }^{11}$

This investigation is characterized as a qualitative case study (ANDRÉ, 1995; LINN; ERICKSON, 1990). One of the motivational aspects of this type of research is its biggest advantage, once it inspires other teachers in this field, who identify themselves with the real context situations. As we build the way through each path we take, according to the poem by Antonio Machado, we hope to inspire other teachers to dare as they walk their path.

The annual extension event ENFOPLE started 15 years ago. It was created in order to instigate discussions about Foreign Languages teachers' education and to disseminate the knowledge constructed by research and by education at the Inhumas campus of UEG. The event has been distinguished from others in the area for offering during its 4-5 days, an English immersion program for preservice and in-service teachers who enroll to participate in its full programming. For the last three editions (2017, 2018, and 2019), there has also been an English workshop for children 9-11 years old (5th graders) from Inhumas public schools, ministered by professors from UEG and other institutions in partnership with EYL teachers from Inhumas, supported by pre-service teachers who volunteer to join the workshop. The Immersion workshops are organized and planned collaboratively by the ENFOPLE coordinators and the team of English teachers and professors invited from other institutions, and also by those who are interested in joining this experience. During the time allotted, pre-service and in-service English teachers from local and non-local schools participate in activities based on the critical questioning perspective (PENNYCOOK, 2001, 2012), that aim at awareness to the foreign language learning and its use, besides using English to discuss interdisciplinary themes considered relevant for the Critical Applied Linguistics field. Concomitantly, it offers a reframing of senses from the problematized themes. The workshops happen in three days, with four different themes and teams acting as the facilitators.

A very unique feature of the ENFOPLE Immersion program for teachers is the collaborative network of English teachers that participate in the planning as well as in the workshop activity. In 2018 there were 12 facilitators divided into four groups who planned each thematic workshop and presented them to the participants. Among them, there were four American Fulbright scholarship holders from UEG and UFG ${ }^{12}$, four teacher educators, and four English teachers. In 2019, we had 20 actively engaged English teachers/professors in the planning process as well as in the classes. Amid them, we had three guest participants from other HEI and from other states, four American Fulbright scholarship holders, and 13 English teachers and educators.

The empirical material discussed in this case study came from two different instruments. We have voice recorded and transcribed reflections pointed by the participants during a post-event meeting ${ }^{13}$ in the 2018 edition. Besides these reflections, we have gathered

\footnotetext{
${ }^{11}$ Campos de Castilla (Edited by de Geoffrey Ribbans ), Madri, Cátedra, 1997. This stanza belongs to «Proverbios y cantares» from the book «Campos de Castilla» and its first edition dates back to 1910 .

${ }^{12}$ Acronym for Goiás Federal University.

${ }^{13}$ Data gathered from the meeting will be addressed as M.
} 
opinions from participants as well as planners and facilitators through an electronic form by Google ${ }^{14}$, after the 2019 edition of the event. In the electronic form sent to all facilitators at the 2019 event, there were three multiple answers questions and other six subjective questions, which demanded descriptive answers. Although the form was sent to all 20 facilitators, only six sent their answers, which will be discussed in this article. We will be looking at three questions, that are:

i.Recite aspects that you have considered relevant for your teacher education;

ii.Is there any general comment about the XV ENFOPLE?

iii.Are there any additional comments about aspects that were not covered by this form?

The participants of this case study are all collaborators of the workshops. The chart that follows presents some information about them, as well as the source of the empirical material we have gathered.

\begin{tabular}{c|c|c|c|c|c} 
Fictitious name & Age & Gender & State/Country & Place of work/study & $\begin{array}{c}\text { Empirical Material } \\
\text { Source }\end{array}$ \\
\hline Isaac & 44 & Male & Goiás/Brazil & UEG/Professor & Meeting (M) \\
\hline Anthony & 24 & Male & Paraná/Brazil & UEL & Meeting (M) \\
\hline Flor & 48 & Female & Goiás/Brazil & UEG/Professor & Electronic Form (EF) \\
\hline Ana & 32 & Female & Paraná/Brazil & PMSP ${ }^{15} /$ USP & Meeting $(\mathrm{M})$ \\
\hline Rose & 40 & Female & Goiás/Brazil & UEG/Professor \\
\hline Pat & -- & Male & USA & Fullbright & Meeting $(\mathrm{M})$ \\
\hline Flora & 25 & Female & Goiás/Brazil & UEG/Undergraduate & Electronic Form (EF) \\
\hline Jacob Will & 19 & Male & Goiás/Brazil & UEG/Undergraduate & Electronic Form (EF) \\
\hline Tuzia & 43 & Female & Goiás/Brazil & English teacher at Inhumas & Electronic Form (EF) \\
\hline
\end{tabular}

Chart 1: Participants

Source: Elaborated by the authors

In the next section, we intend to discuss some of the collaborators' perceptions, namely, pre-service and in-service English teachers, and educators. We also present some aspects that ground the ENFOPLE and the Immersion Program for teachers from the coordinators' points of view.

\footnotetext{
${ }^{14}$ Data gathered from the electronic Google form will be addressed as EF.

${ }^{15}$ Prefeitura Municipal de São Paulo
} 


\section{WHAT DO THE COLLABORATORS SAY ABOUT THE EVENT?}

As teacher educators at UEG, we have developed the ENFOPLE as an extension event focused on foreign languages teachers' education, and we have also launched the English Immersion Program for Teachers as an effort to bring international intercultural experiences through the critical thematic workshops, planned and performed by experienced teachers, in order to promote IaH in a context where a foreign language is not only thought but also lived, as referred by the participant Rose in the epigraph of the article.

In an effort to answer the questions proposed in this paper we take a look at some of the discourse that emerged from both instruments. To discuss the relationship between the ENFOPLE event and the internationalization process at UEG, we consider it essential to recall the locus where the events happen. Inhumas is a small city, in the metropolitan area of Goiania, the state capital of Goiás, where most pre-service teachers of our Letras (Portuguese and English Language) Course need to work full-time and study in the evening. As a strategy to bring more students and teachers from our local community to experience interacting in a foreign language, we purposeful try, with the immersion program curriculum, to integrate international and intercultural dimensions into the undergraduate students learning environments (BEELEN; JONES, 2015), characterizing in our opinion, a strategy for IaH. When reflecting upon the immersion curriculum based on a critical perspective that included themes like race, social differences, environmental issues, sex and gender, among others, Pat says:

I think that the topics you guys chose were awesome, like [...] it challenged really efficient speakers because it's hard to formulate thoughts in a different language like social issues of your identity. I don't know what all the topics were but the way it was organized was great, in... like a real chance for fluent speakers or maybe people who could formulate shorter sentences. I think it's like what's good for everybody and last year I think that we were very fluent and more [...] because they played a lot more games so I think it was better organized this year with the workshops. I think it engaged more people. (PAT, M, 2018)

The workshops planned in 2018 were based on the critical perspective of language teaching (PENNYCOOK, 2001), with topics 'that challenged efficient speakers' and at the same time for 'people who could formulate shorter sentences', according to Pat. We have found that through activities in which social themes are discussed in pairs and groups, participants can speak up their opinions in different levels of fluency, with scaffolding from a more experienced pair or the facilitators. Each group is composed of 3 or 4 teachers who go around the class motivating the discussion of the workshop's participants or giving support for their ideas structuring.

As far as the critical perspective that grounds the workshop creation, Ana (EF, 2019) reinforces the importance of developing teachers' critical thinking in order to promote experiences in class that provoke questioning, reframing standardized meanings (BORELLI, 2018; SILVESTRE, 2017):

As an English for children teacher educator, the moment has made me strengthen the belief that critical English teaching for children actually begins in the teachers' critical thinking. (ANA, EF, 2019)

During the post-event meeting, other features of the immersion program for teachers were mentioned, regarding the teacher education purposes, besides the language practices:

In my opinion, the main gain that I had was that students would have... it's not language: it's watching the practice, [...] I think that is what the students are missing, it is the opportunity to see how to do things. (TATI, M, 2019)

As mentioned by Tati, an important aspect of the immersion experience for undergraduate students was 'the opportunity to see how to do things', in other words, getting to know what is a sequence of activities, how to motivate students, class management, as well as the decision making process corroborating Kumaravadivelu (2003, 2006). Regarding the teacher education enabled by the extension event, including the planning and the acting in classes, one of the facilitators who participated in the 2019 edition emphasized some aspects related to his education. Although Anthony is a Ph.D. student from another state as well as an experienced English teacher and educator, the ENFOPLE event, in his opinion, provided: 
Experience in a diverse educational context, metathesis from theory to practice, an opportunity for reflecting on my own teaching practice process; an opportunity for new partnerships. (ANTHONY, EF, 2019)

The aspects mentioned above by the participant confirm that besides the focus on the IaH experience, ENFOPLE is an event that supports cutting edge teacher education as mentioned by Darling-Hammond (2006) and Zeichner (2010) regarding the defiances for 21st-century teachers. When presenting aspects that could be highlighted referring to their education both pre-service teachers (Jacob Will and Fora) as well as in-service English teachers (Luzia and Teacher H) pointed out diverse advantages such as:

The actual opportunity to teach, plan, and also to see the creativity when you don't have a lot of material (such as using mirrors). (JACOB WILL, EF, 2019)

The learning, the experience, and the knowledge. (FLORA, EF, 2019)

A new perspective about planning and about class strategies. Methodological enrichment. Motivation. (TEACHER H, EF, 2019)

Approach a social theme during English class (LUZIA, EF, 2019)

As stated by the participants, there were diverse features that may contribute to their praxis, reaffirming Zeichner (2010) in relation to connecting English teachers to the real context, including planning, methodological procedures, motivation, among other aspects. When we look into ENFOPLE outcomes, it is possible to note the role of the community's involvement and also the goals, the environment, and the returns of the partnership (DOUGLAS; ELLIS, 2011; FURLONG et al., 2006; BREAULT, 2013) among schools (public and private), local community and university built over the years, through the extension events we have created such as ENFOPLE, the English Immersion Program for Teachers and the English for Kids Program.

Moving on to the final analysis, we consider it necessary to display the ENFOPLE coordinators' point of view on the event, when questioned regarding the scope, students' participation among other issues:

We think that the Immersion program should be free because I want students to come. (FLOR, M, 2018).

Most of them work, the others don't want to come. Others won't come because it's 3 days long. So it depends on the decision of each one, and deciding to come is also important at this moment that's why I told you the first day: "Don't worry about having few students in the classroom", we are doing our best. Of course, it's an expensive program because you see many hours of work and everything. So it will be better to have more students but we think that being here once a week or 2 hours a day, they (...) have this opportunity in another moment. But they don't have an opportunity to stay thinking and speaking and listening all day long for 2 or 3 days. (FLOR, M, 2018)

As stated by the ENFOPLE coordinator, although the English Immersion Program for Teachers involves a great number of collaborators, and a long time for its planning, one of the challenges of the community is to gather more participants. ENFOPLE's coordinators reinforce the program's gratuity, in order to meet one of the extension goals of serving the society by means of the university research and teaching (MIGUENS JR; CELESTE, 2014). Besides, through the extension event and programs, we keep the social aspect of UEG Idioms Center as it interrelates theory and practice for teachers (BROSSI; SILVA; FREITAS, 2019). On the other hand, the centrality of the human factor, the feelings provoked and the social relations are also an essential part of the whole endeavor, according to the coordinators:

Just for the record, our campus is really interested in this kind of program, that's why we are promoting a second one [...] Because we take all the chances we have to learn, to know people and say: "Guys, we are close to Goiania, please come with us". (ISAAC, M, 2019) 
I just want to say thank you! For each of you. It was so nice, you really got involved in this program in a way that I could never imagine, we kept in contact all the time [...] it's very nice having you here guys! [...] it was something like a good vibration, like last night... I cannot explain the very good vibration from you guys and all the time I think that we are using language in order to change lives I think we could do that probably would change our lives and probably we could change lives of others ${ }^{16}$, of the participants here. I think it was really important with our attitude, and think of what you did and you spoke and everything (ROSE, M, 2018)

Rose's statement meets what Kochhann (2019) advocates in the sense that extension activities may provide transformation in one's life, as well as in a community, since a change in attitudes may lead to a transformation in relations and in the community, as a whole.

Next, we construct our final utterances even though we still have much to say about the fifteen editions of the ENFOPLE. We resume the guiding questions that led this study, as we briefly present our conclusions, contributions to the field, and referrals to future studies.

\section{FINAL REMARKS}

First of all, the question that sparked the present study was i) What is the relation between the ENFOPLE extension event and UEG's internationalization process? We presented the origins of the ENFOPLE as an extension event that began inspired by an English Immersion Program promoted by a partnership among different social realms that motivated international and intercultural experiences using the foreign language as a social practice. Although UEG's discourse about internationalization materialized way after 2006 (about 10 years after), the Artslit program was a kick-off for IaH experiences. Through ENFOPLE's trajectory, Immersion Programs for teachers were resumed in 2017, upholding partnerships for exchanging experiences through curricular additions.

The other question that guided us into writing this article was ii) What are teachers' perceptions regarding ENFOPLE and their own education? The teachers involved in the event, participants and collaborators had diverse perceptions regarding their education that can be summarized as contributions to their planning, the methodology, their motivation to teach, the process of reflecting upon their practice, among others.

We consider that this study brings a discussion that may contribute to the field of critical internationalization as we present a small step promoted by a community extension event that could bring IaH closer to distant contexts, of this young HEI as well as other institutions. This study may also bring contributions to the extension field of studies, as for the teachers' education field of study, once it supports curricular enrichment for teachers' education through extension activities.

Finally, we summon up pre-service and in-service teachers, educators, and other stakeholders from extension events that encourage foreign language social practice, to discuss the activities, to investigate their occurrence in order to present strategies for IaH as a local opportunity for communities, such as ours.

At last, from the testimonies gathered during the post-event meeting in 2018, it is very clear that we have been facing internationalization, as well as other challenges such as teacher education, low government investment in education, among others as a community, other than a team, an academic group, or as a faculty. The way we see it, we are a unified body of individuals united by similar interests, wishes, and motivations, highly integrated by common goals and especially by sympathy ties. A community that back in 2006 established partnerships that promoted a very unique encounter with common goals related to foreign language learning and social practice. That was the kickstart for thoughts of internationalization in our community. Not for UEG, not for the English teachers of Inhumas, and not even for the American professors that presented us with Artslit. For the community. As a community, we have undertaken the ENFOPLE event for 15 years. And as a community, we have been struggling to advocate a learning space among government educational budget cuts. As a community, we have been trying to provide our local low-income

${ }^{16}$ Highlighted by authors.

Freitas, Brossi \& Rosa-da-Silva | Small stepsand a big change: facing internationalization as a community 
pre-service teachers with international and intercultural curriculum experiences. As a community, we have also been expanding through much of what we like to be characterized by personal relations with deep feelings of gratitude for every partner we have conquered. Therefore, opposed to extension events with hundreds of people in metropolitan HEI, we take small steps locally, involving huge actions such as foreign languages immersion for few people and still we see big changes. We see English teachers who have found the motivation to continue learning. We see partners who come from other countries and other states to voluntarily work as a facilitator in our event. We see students who dream of getting a scholarship to experience foreign languages abroad. We see teacher educators who exchange knowledge horizontally in an effort for decolonizing internationalization. As a community, we emphasize one of ENFOPLE's coordinator discourse: "Don't worry about having a few students in the classroom, we are doing our best".

\section{ACKNOWLEDGMENTS}

Special Thanks: First we thank professor Christiane Castro Brossi (SFUSD) for the careful reading and language review. We also express our gratitude to the research groups we participate for the discussions that have been inspiring us: FELICE, coordinated by Professor Juliana Tonelli, GEFOPLE, coordinated by Professor Carla Conti de Freitas and GT Transição coordinated by professors Rosane Pessoa and Viviane Silvestre. You have changed our lives!

\section{REFERENCES}

ANDRÉ, M. E. D. A. Etnografia da prática escolar. Campinas: Papirus, 1995.

BAUMAN, Z. Modernidade líquida. Rio de Janeiro: Zahar, 2001.

BAUMVOL, L. K. ; SARMENTO, S. A internacionalização em Casa e o uso de inglês como meio de instrução. In: BECK, M. S.; MORITZ, M. E.; MARTINS, M. L. M.; HEBERLE, V. (org.). Echoes: Further Reflections on Language and Literature. Florianópolis: UFSC, 2016. p. 65-82.

BEELEN, J.; JONES, E. Redefining internationalization at home. In: CURAJ, A. et al. (ed.). The European Higher Education Area: Between Critical Reflections and Future Policies, Springer, p. 59-72, 2016.

BORELLI, J. D. V. P. O estágio e o desafio decolonial: (des)construindo sentidos sobre a formação de professores/as de inglês. 2018. 222 f. Tese (Doutorado em Letras e Linguística) - Universidade Federal de Goiás, Goiânia, 2018.

BREAULT, D. A. The challenges of scaling-up and sustaining professional development school partnerships. Teaching and Teacher Education, v. 36, p. 92-100, 2013.

BROSSI G. C.; SILVA M. P. English for kids: ensino e pesquisa na extensão. In: FREITAS, C. C. et al. (org.). Diálogos entre a universidade e a escola na (trans)formação de professores de língua. Anápolis: Ed. UEG, 2018. p. 227-248.

BROSSI G. C.; SILVA, V. R.; FREITAS, C. C. English for kids project: reframing teaching and research through extension. In: SILVA, A. et al. (org.) Information management, education and technology. Covilhã : Universidade da Beira Interior, 2019. p. 145-169

BROSSI, G. C. Políticas Educacionais e Formação Crítica de Professores de Língua Inglesa para as Séries Iniciais do Ensino Fundamental: Desdobramentos e Construções Colaborativas. Tese (Doutorado em Estudos da Linguagem) - Universidade Estadual de Londrina, Londrina, (in press). 
DARLING-HAMMOND, L. Constructing 21st-Century Teacher Education. Journal of Teacher Education. v. 57, n. 3, p. 300-314, $2006 a$.

DARLING-HAMMOND, L. Addressing the dilemmas of teacher education: evidence of success. In: Powerful Teacher Education: lessons from exemplary programs. San Francisco: Jossey-Bass. 2006b. p. 42-74.

DE WIT, H.; DECA, L.; HUNTER, F. Internationalization of Higher Education - What can Research add to the Policy Debate? In: CURAJ, A. et al. (ed.). The European Higher Education Area: between critical reflections and future policies, Springer, p. 3-12, 2018.

DOUGLAS, A. S.; ELLIS, V. Connecting does not necessarily mean learning: course handbooks as mediating tools in schooluniversity partnerships. JournalofTeacherEducation, v. 62, n.5, p. 465-476, 2011.

EGÍDO, A. A., BROSSI, G. C. O Planejamento Telecolaborativo de professores de língua inglesa por meio de dispositivos tecnológicos. Revista UFG, n. 19, p. 1-16, 2019. Disponível em: https://doi.org/10.5216/revufg.v19.60858. Acesso em: 20 dez. 2019.

LINN, R. L.; ERICKSON, F. (org.). Quantitative methods; Qualitative Methods. v.2. New York: Macmillan, 1990.

FINARDI, K. R.; ARCHANJO, R. Washback effects of the science without borders, english without borders and language without borders programs in brazilian language policies and rights. In: SIINER, M.; HULT, F.; KUPISCH, T. (org.). Language policy and language acquisition planning, Springer, p. 173-185, 2018.

FINARDI, K. R. Internationalization and multilingualism in Brazil: Possibilities of content and language integrated learning and intercomprehension approaches. InternationalJournalofEducationalandPedagogicalSciences, v. 13, p. 656-659, 2019.

FORTES, R. Política científica no Brasil: dilemas em torno da internacionalização e do inglês, Interfaces Brasil/Canadá. Canoas, v. 16, n. 1, 2016, p. 142-180.

FREITAS, C. C. Artslit e a formação lúdica do professor de língua inglesa. In: ROCHA, C. H. ; TONELLI, J. R. A.; SILVA, K. A. Língua estrangeira para crianças: ensino-aprendizagem e formação docente. Campinas, SP: Pontes Editores, 2010. p. 203-219

FURLONG, J. et al. Partnership in English ITE: changing times, changing definitions - evidence from the Teacher Training Agency National Partnership Project. ScottishEducationalReview, v. 37, p. 32-45, 2006. Disponível em: http://www.scotedreview.org.uk/view issue.php?id=37\%5Bspecial\%5D. Acesso em: 28 jul. 2008.

GARSON, K. Reframing internationalization. Canadian Journal of Higer Education. Burnaby, v. 46, n. 2, p. 19-39, 2016.

GEE, J. P. New people in new worlds: networks, the new capitalism and schools. In: COPE, B.; KALANTZIS, M. (ed.). Mutliliteracies: literacy learning and the design of social futures. London; New York: Routledge, 2000. p. 43-68.

KENNEDY, C. Models of change and innovation. In: HYLAND, K.; WONG, L. (ed.). Innovation and change in English Language Education. London; New York: Routledge, 2013. p. 13-27.

KNIGHT, J. Internationalization remodeled: Definition, approaches, and rationales. JournalofStudies in InternationalEducation, v. 8, n. 1, p. 5-31, 2004.

KOCHHANN, A. Formação docente e extensão universitária: tessituras entre concepções, sentidos e construções. $2019.548 \mathrm{f}$. Tese (Doutorado em Educação)-Universidade de Brasília, Brasília, 2019.

KUMARAVADIVELU, B. Beyond methods: Macrostrategies for language teaching. New Haven, CT: Yale University Press, 2003. 
KUMARAVADIVELU, B. Understanding language teaching: From method to postmethod. Mahwah, NJ: Lawrence Erlbaum Associates, 2006.

MIGUENS JR. S. A. Q.; CELESTE, R. K. A extensão universitária. 2014 . Disponível em: https://www.researchgate.net/publication/253645827 A EXTENSAO UNIVERSITARIA - Capitulo de Livro. Acesso em: 20 dez. 2020.

PENNYCOOK, A. Critical Applied Linguistics: a critical introduction. New Jersey: Lawrence Erlbaum Associates, Inc. 2001.

PENNYCOOK, A. Language and mobility. Unexpected places. Bristol: Multilingual Matters, 2012.

PICCIN, G.F.O.; FINARDI, K. R. Questioning Global Citizenship Education in the Internationalization Agenda. SFU Educational Review, v.12, n.3, p.73-89, 2019. Disponível em: https://doi.org/10.21810/sfuer.v12i3.1015. Acesso em: 20 dez. 2020.

PRADO, A. F.; FREITAS, C. C. de. Evento científico e a formação de professores: caso do encontro sobre formação de professores de língua estrangeira da UEG Câmpus Inhumas. In: CONGRESSO DE ENSINO, PESQUISA E EXTENSÃO DA UEG (CEPE), 2. Anápolis: UEG, 2015. Anais... Anápolis: UEG, 2015. p. 1-8

SILVESTRE, V. P. V. Colaboração e crítica na formação de professores de línguas: teorizações construídas em uma experiência com o Pibid. Campinas: Pontes, 2017.

SOUSA SANTOS, B. Um discurso sobre as ciências. São Paulo: Cortez Editora, 2018.

STRECK, D.; ABBA, J. Internacionalização da educação superior e herança colonial na América Latina. In: KORSUNSKY, L. et al. (coord.). Internacionalizacióny producción de conocimiento: el aporte de las redes académicas. Ciudad Autónomade Buenos Aires: IEC - CONADU; Ciudad Autónoma de Buenos Aires: CLACSO, 2018. P.113-131. Disponível em: https://www.researchgate.net/publication/327075225 INTERNACIONALIZACAO DA EDUCACAO SUPERIOR E HERA NCA COLONIAL NA AMERICA LATINA. Acesso em: 30 abr. 2020.

TAVARES, D. S. ; FREITAS, C.C. Multiletramentos na formação de professores de línguas. REVELLI [Dossiê Multiletramentos, tecnologias e Educação a Distância em tempos atuais.], v.10, n.3, p.151-173, set. 2018.

ZEICHNER, K. Rethinking the connections between campus courses and field experiences in college and university-based teacher education. Educação, Santa Maria, v. 35, n. 3, p. 479-501, set./dez. 2010.

\section{()(1) $\circledast$}

Received in April 30 13, 2020. Approved in August 17, 2020. 